\title{
Linking Human Resources Practices to Corporate Entrepreneurship: The Mediating Role of Perceived Organizational Support
}

\author{
Ata Özdemirci \\ (Corresponding author) \\ Marmara University, Faculty of Business Administration, \\ Ressam Namık İsmail Sokak No:1 Bahçelievler/ Istanbul, 34180, Turkey \\ Tel: 90-212-5079925Ｅ-mail: ataozdemirci@gmail.com \\ Nihal Kartaltepe Behram \\ Marmara University, Faculty of Business Administration, \\ Ressam Namık İsmail Sokak No:1 Bahçelievler/ Istanbul, 34180, Turkey \\ Tel: 90-212-5079925Ｅ-mail: nihalkartaltepe@gmail.com
}

Received: January 16, 2014 Accepted: March 2, $2014 \quad$ Published: June 5, 2014

doi:10.5296/bms.v5i1.4976 URL: http://dx.doi.org/10.5296/bms.v5i1.4976

\begin{abstract}
The purpose of this study was to develop a mediation model in which high-performance human resource practices affect corporate entrepreneurship through perceived organizational support. In accordance with this purpose, firstly, the interrelationships between specific human resources practices (selective staffing, extensive training, internal mobility, employment security, clear job description, result-oriented appraisal, incentive reward, and participation) and corporate entrepreneurship dimensions (new business venturing, innovativeness, self-renewal, proactiveness) were examined. Then, based on social exchange theory, the mediating role of perceived organizational support in the relationship between human resources practices and corporate entrepreneurship was investigated. Data was collected through a survey, in which 258 medium and large scaled firms operating in different
\end{abstract}


industries in Turkey participated. The results provide empirical evidence for the strong impact of human resources practices on corporate entrepreneurship, and this relationship is mediated by perceived organizational support of employees.

Keywords: Corporate Entrepreneurship, Human Resources Practices, Organizational Support 


\section{Introduction}

As companies move from one stage of their cycle to the next, they often have to revamp their skills and build innovative capabilities to survive, achieve profitability, and stimulate growth. Corporate entrepreneurship activities give these firms a foundation for building and exploiting these capabilities (Zahra et al., 2009). Therefore, corporate entrepreneurship within organizations is regarded as a means towards increased organizational growth, strategic renewal, organizational change, and customer value added services (Shaw et al., 2005). Consequently organizations today are looking for ways to become more and more entrepreneurial. The question that arises here is "What factors foster and facilitate entrepreneurship?" This study breaks the answer into two relevant components: human resources practices and perceived organizational support.

While there are several facilitation strategies available to organizations that can be helpful in fostering an entrepreneurial environment, a successful alignment of the organization's human resource management practices and policies is possibly the most effective (Rutherford and Holt, 2007) because corporate entrepreneurship rests upon an organization's ability to learn through both exploration of new knowledge and exploitation of existing knowledge. These learning processes are dependent upon an organization's intellectual capital and, in particular, human and social capital (Hayton, 2005). In this context, we suggest that human resources management practices as factors shaping human and social capital are vital to foster and facilitate corporate entrepreneurship. High-performance human resource practices enhance employee skills, their participation in decision-making, and their motivation to exert discretionary or spontaneous efforts (Appelbaum et al., 2000), and in doing so become an important driver of corporate entrepreneurship.

Over the past three decades, a growing body of literature has emerged that focuses on the association between human resource management practices and corporate entrepreneurship (Morris and Jones, 1983; Schuler, 1986; Kuratko et al., 1990; Hornsby et al., 1999; Twomey and Harris, 2000; Hayton, 2004; Kaya 2006; Zhang et al. 2008; Schmelter et al, 2010; Zhang and Jia 2010). However, only a few studies have examined the influence of human resource practices on a firm's overall corporate entrepreneurship and explained how human resource practices directly influence corporate entrepreneurship (Zhang et al., 2008). Accordingly, in this study, we aim to extend the existing literature in several ways. Firstly, we analyze the influence of eight specific human resources management practices on overall corporate entrepreneurship: selective staffing, extensive training, internal mobility, employment security, clear job description, result-oriented appraisal, incentive reward, and participation (Zhang and Jia, 2010). Second, by incorporating the construct of perceived organizational support, we attempt to explain the link between human resources practices and corporate entrepreneurship using the social exchange perspective. Our study aims to contribute to the corporate entrepreneurship literature by developing a mediation model in which human resource practices affect corporate entrepreneurship through perceived organizational support. 
The purpose of this study is therefore twofold: (1) to analyze the influence of specific human resources practices on corporate entrepreneurship and distinguish between specific human resources practices based on their importance for corporate entrepreneurship; (2) to investigate the mediating role of perceived organizational support in the relationship between human resources practices and corporate entrepreneurship.

\section{Literature Review and Hypotheses}

\subsection{Corporate Entrepreneurship}

Since the beginning of the 1980s the phenomenon of entrepreneurship within existing organizations has transformed to corporate entrepreneurship and has attracted the interest of both scholars and practitioners (Antoncic and Hisrich, 2001). Zahra (1995:226) describes corporate entrepreneurship as "the sum of a company's innovation, venturing and renewal efforts". Covin and Miles (1999:50) describe corporate entrepreneurship as "the presence of innovation plus the presence of the objective of rejuvenating or purposefully redefining organizations, markets, or industries in order to create or sustain competitive superiority". Kuratko et al. (2005:700) suggest that corporate entrepreneurship represents a set of behaviors "requiring organizational sanctions and resource commitments for the purpose of developing different types of value-creating innovations".

Antoncic and Hisrich (2001) considered previous definitions and measures of corporate entrepreneurship and argued that the previous dimensions could be reclassified into these four dimensions: new business venturing, innovativeness, self-renewal and proactiveness. The new business venturing dimension refers to new business creation within an existing organization by redefining the company's products (or services) and/or by developing new markets. Antoncic and Hisrich (2003) considered this dimension an integral component of entrepreneurship, given the importance of entrepreneurial firms pursuing new business venturing by redefining the company's products or markets. The new business venturing dimension includes the Lumpkin and Dess (1996) dimension of autonomy, which referred to independent actions of individuals or teams aimed at bringing forth a business concept or vision and carrying it through to completion. The innovativeness dimension refers to product and service innovation with emphasis on development and innovation in technology. Entrepreneurship includes new product development, product improvements, and new production methods and procedures. Covin and Slevin (1991) considered one part of the entrepreneurial posture that reflected itself in the extensiveness and frequency of product innovation and the related tendency of technological leadership. Knight (1997) included the development or enhancement of products, services, and techniques and technologies in production as part of organizational innovativeness. Zahra (1993) included product innovation and technological entrepreneurship as innovative aspects of manufacturing firms. The self-renewal dimension reflects the transformation of organizations through the renewal of key ideas on which they are built. It has strategic and organizational change connotations and includes the redefinition of the business concept, reorganization, and the introduction of system-wide changes for innovation. Zahra (1993) considered the self-renewal construct to 
comprise strategic and organizational change and to include the redefinition of the business concept, reorganization, and the introduction of system wide changes for innovation. Covin and Miles (1999) consider the strategic renewal concept to be related to the phenomena whereby the organization seeks to redefine its relationship with its markets or competitors by fundamentally altering how it competes. Finally, the proactiveness dimension is related to aggressive posturing relative to competitors. A proactive firm is inclined to take risks by conducting experiments. It takes initiative (Lumpkin and Dess, 1996) and is bold and aggressive in pursuing opportunities (Covin and Slevin, 1991). The concept of proactiveness "refers to the extent to which organizations attempt to lead rather than follow competitors in such key business areas as the introduction of new products or services, operating technologies, and administrative techniques" (Covin and Slevin, 1986, p. 631). Proactiveness includes initiative and risk taking and the competitive aggressiveness and boldness that are reflected in orientations and activities of top management (Antoncic and Hisrich, 2001).

\subsection{Human Resources Practices and Corporate Entrepreneurship}

In the existing literature, there is a growing interest in human resources practices as an antecedent to corporate entrepreneurship (Schuler, 1986; Kuratko et al., 1990; Morris and Jones, 1993; Hornsby et al., 1999; Twomey and Harris, 2000; Hayton, 2004; Kaya 2006; Zhang et al. 2008; Schmelter et al, 2010; Zhang and Jia 2010).

Schuler (1986) argues that consistent human resources practices can improve entrepreneurship and suggests that the following employee characteristics are associated with successful entrepreneurial efforts: creative and innovative behavior, risk taking, long-term orientation, focus on results, flexibility to change, cooperation, independent behavior, tolerance of ambiguity, and a preference to assume responsibility. Accordingly, to increase the likelihood of systematic innovation and thereby foster and facilitate entrepreneurship, organizations need to stimulate and reinforce these characteristics via human resource management practices. In a study of 112 firms from a wide range of industries, Morris and Jones (1993) identify five sets of human resources practices associated with corporate entrepreneurship: performance appraisals; compensation; orientation and training; recruitment and career development; and job design. Firstly, Morris and Jones assume that performance appraisals are oriented towards ends rather than means; they measure both individual and group performance; they include innovation and risk taking; they reflect a tolerance for failure; and they take into account a longer time frame for corporate entrepreneurship than for traditional administrative management. Second, in entrepreneurial firms, compensation emphasizes external equity rather than internal equity; base pay is lower and there is a greater amount of pay at risk. Entrepreneurial firms also balance both long and short-term performance and individual and group performance. Third, entrepreneurial firms invest more time and effort in orientation and there is more group oriented training. Fourth, entrepreneurial firms emphasize the external labor market and offer a variety of career paths. Finally, job designs tend to be less structured and more complex, offering more discretionary authority and freedom. Hornsby, Kuratko, and Montagno (1999) identify five success factors 
linking human resources practices to corporate entrepreneurship. These include the appropriate use of rewards, the provision of management support for innovation, the availability of resources for innovation, an organizational structure conducive to learning and cooperation, and individual risk taking. Hayton (2004) distinguishes 'discretionary' HRM practices from 'traditional' practices. Discretionary practices such as incentive pay, employee suggestion schemes, and formal employee participation programs are those which encourage employee commitment, cooperation, knowledge sharing and voluntary, extra-role behaviors. In contrast, traditional HR practices focus upon defining jobs, staffing jobs through a matching process, and monitoring prescribed performance. In a study on US small and medium sized enterprises, Hayton (2004) provides evidence that discretionary practices promote corporate entrepreneurship and that this relationship is strongest for firms operating in high technology industries.

The widely documented relationship between human resource practices and corporate entrepreneurship has been explained in a variety of ways. One explanation is that enhancement of employee skills and of the motivation to use those skills leads to creativity improvement (Sun et al., 2007). Employees will not only use their skills to enhance core job performance but will also suggest innovative ideas that will improve corporate entrepreneurship. High-performance human resource practices consist of finding ways of investing in employees' knowledge and skills. However, some kinds of tacit knowledge remain intangible, idiosyncratic and difficult to imitate or duplicate, even though they play a vital role in corporate entrepreneurship. From the perspective of social exchange theory, the employment relationship will obligate employees to reciprocate the organization's inducements with discretionary role behaviors such as organizational citizenship behavior to contribute more to the organization (Podsakoff and MacKenzie, 1997). On the other hand, if there is a low degree of organizational citizenship behavior in the work context, employees will have no motivation or inclination to contribute more creative ideas for corporate entrepreneurship (Zhang et al., 2008).

\subsection{The Mediating Role of Organizational Support}

Recent research has shown the utility of conceptualizing perceived organizational support as a factor capable of mediating the relationship between independent and dependent variables. For example, Wayne et al. (1997) found that perceived organizational support affected the association between human resource practices and affective commitment, organizational citizenship behaviors, and the intent to quit. Moreover, Allen et al. (2003) reported that perceived organizational support mediated the relationship between commitment and decision-making, job security, and fairness of rewards. Rhoades et al. (2001) found that perceived organizational support influenced the relationship between commitment and organizational rewards, procedural justice, and supervisor support. Further, Moorman et al. (1998) reported that perceived organizational support mediated the association between perceived organizational support and extra-role behaviors. Perceived organizational support has also been shown to alter the perceived supervisor support-voluntary turnover relationship 
(Eisenberger et al., 2002). Finally, recent research has shown that procedural justice perceptions affect work outcomes (e.g., commitment, satisfaction, intent to quit) via the influence of perceived organizational support (Masterson et al. 2000). Based on these studies, it appears that perceived organizational support possesses great potential to influence many work relationships (Hochwarter et al., 2003).

organizational support suggests that employees develop perceptions regarding the degree to which their organization values their contributions and the amount of concern exhibited towards their wellbeing. The underpinnings of perceived organizational support are derived from social exchange theory which was developed to explain interpersonal relationship maintenance in the context of the work environment. Once individuals assess the organizational support they receive, they act in accordance with a norm of reciprocity. Thus, when an individual perceives the organization to be supporting them by valuing their contribution to the organization and by indicating concern for their well-being, the individual will then feel obligated to be committed to the organization and will show this commitment through increased work efforts (Ring, 2010).

To support the idea that perceived organizational support mediates the relationship between human resources practices and corporate entrepreneurship, human resources practices must be considered as an antecedent of perceived organizational support. High-performance human resource practices are important for managing the employment-organization relationship, particularly through programs such as skills training, long-term-result-oriented appraisals, and significant open-ended rewards. By satisfying the employees' needs, these practices foster the perception among employees that they are receiving a high level of organizational support. Based on this discussion, high-performance human resource practices appear to contribute to employees' perceived organizational support (Zhang and Jia 2010).

According to social exchange theory employees who perceive their organizational environment as supportive will feel obligated to reciprocate with behaviors that are beneficial to the organization. From this viewpoint, it could be expected that perceived organizational support mediates the effects of human resources practices on corporate entrepreneurship, because positive feelings about the organization and its supportive nature could positively influence employees' receptivity towards the organization's efforts to introduce and implement corporate entrepreneurship (Rutherford and Holt, 2007). Antoncic and Hisrich (2004) also suggest that organizational support characteristics such as management support, work discretion, rewards, time availability, and loose intra-organizational boundaries have been seen to be crucial organizational elements impacting corporate entrepreneurship.

According to Zhang and Jia (2010), if the perceived organizational support is positive, employees will be proactive and innovate on their own initiative. If the perceived organizational support is negative, however, employees will lack motivation or inclination to contribute creative ideas for corporate entrepreneurship. Thus, we expect that the perceived organizational support will mediate the relationship between human resource practices and corporate entrepreneurship. This leads us to suggest that: 


\section{IIMacrothink}

$\mathrm{H}_{1}$ : Perceived organizational support mediates the effects of human resource practices on corporate entrepreneurship.

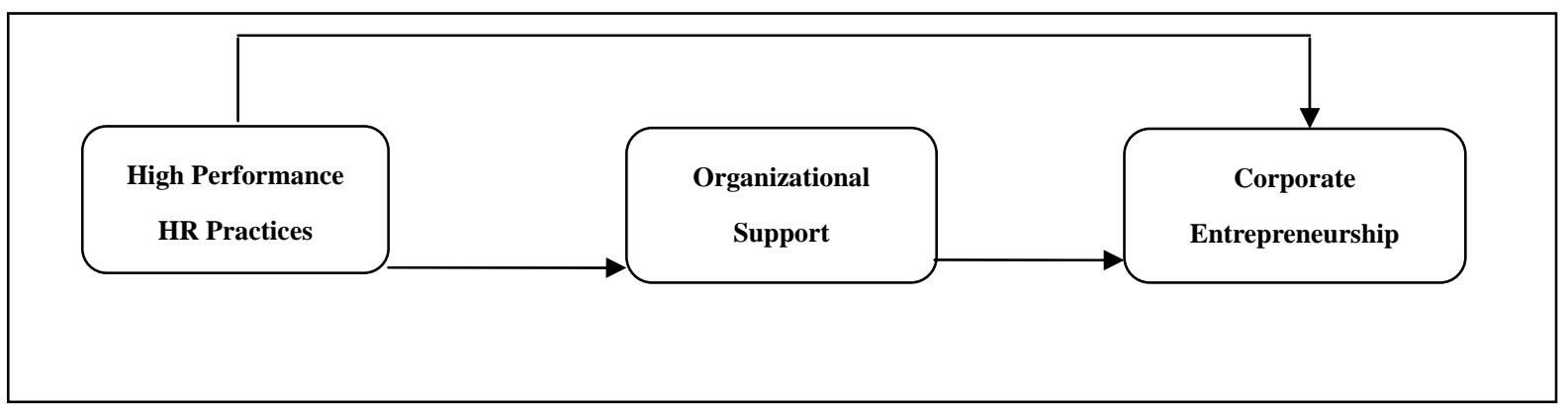

Figure 1. Research Model

\section{Methodology}

\subsection{Sample and Data Collection}

This research was applied to establishments which operate in Istanbul, are members of the Chamber of Industry of Istanbul, are medium and large sized companies, have more than 50 employees, and apply HR functions. There was no restriction on the sector. Samples were selected from the Istanbul Chamber of Industry database randomly.

Face-to-face surveys and online surveys were conducted on the middle and top level managers. After the translation of the measures, a back-translation by a professional translator was used to check the accuracy of the original translation. The two versions were compared to ensure accuracy. After the survey process, 271 surveys were filled and 258 of them were approved. $76.2 \%$ of the firms were medium sized companies with workers between 50 and 250 and the rest of the firms were large sized with more than 250 workers. 54,3\% of all respondents were male. The respondents' ages were mostly between 20 and 40, and nearly all of the respondents were graduates or held higher degrees.

Table 1. Demographics of Respondents

\begin{tabular}{lcc}
\hline & $\mathrm{f}$ & $\%$ \\
\hline Sex & & \\
$\quad$ Female & 118 & $45.7 \%$ \\
$\quad$ Male & 140 & $54.3 \%$ \\
Age & & \\
$\quad 20-29$ & 154 & $59.7 \%$ \\
$30-39$ & 76 & $29.4 \%$ \\
$40-49$ & 13 & $5.1 \%$ \\
$\quad 50$ Or More & 15 & $5.8 \%$ \\
Education & & \\
$\quad$ Primary & 6 & $2.3 \%$ \\
$\quad$ High School & 9 & $3.5 \%$
\end{tabular}




\begin{tabular}{lcc} 
Graduate & 152 & $58.9 \%$ \\
Postgraduate & 88 & $34.1 \%$ \\
Doctorate & 3 & $1.2 \%$ \\
\hline
\end{tabular}

\subsection{Measures}

The survey prepared for the research consisted of 61 questions. As seen in Table 2, the measure of corporate entrepreneurship (Antoncic and Hisrich, 2003; Özdemirci, 2011) had 16 items, the measure of High Performance HR Practices (Zhang and Jia, 2010) had 28 items, and the measure of Perceived Organizational Support (Eisenberger et al., 1997, Rhoades et al., 2001, Zhang and Jia, 2010) had 8 items. There were also 8 questions about the demographics and 1 question about firm size. Likert Scale-5 was used in all questions.

Table 2. Measures Used in Research

\begin{tabular}{llc}
\hline Measure & Developers & Item \\
\hline Corporate Entrepreneurship & Antoncic and Hisrich (2003); Özdemirci (2011) & 16 \\
High Performance HR Practices & Zhang and Jia (2010) & 28 \\
& Eisenberger et al. (1997), Rhoades et al. (2001), & 8 \\
Organizational Support & Zhang and Jia (2010) \\
\hline
\end{tabular}

\subsection{Analysis and Data Extraction Method}

Structural equation modeling (SEM) was used for testing the research model. Before the SEM process, PASW Statistics 18 was used for expletory factor analysis, reliability analysis and correlation analysis. After these analyses, confirmatory factor analysis and model testing was applied by Lisrel 8.51.

\subsection{Factor Analysis and Reliabilities}

After the factor analysis, three factors which can be labeled "New Business Venturing - Self Renewal", "Innovativeness" and "Proactiveness" emerged in Corporate Entrepreneurship Measure; six factors which can be labeled "Clear Job Descriptions - Result Oriented Appraisal", "Extensive Training", "Selective Staffing", "Employment Security", "Participation", "Internal Mobility" emerged in High Performance HR Practices Measure; and one factor which can be labeled "Organizational Support" emerged in Perceived Organizational Support Measure. In the corporate entrepreneurship measure, "New Business Venturing" and "Self Renewal" dimensions were conjoined in one dimension. In the High Performance HR Practices Measure, "Clear Job Descriptions" and "Result Oriented Appraisal" were conjoined and the "Incentive Reward" dimension disappeared. Organizational Support remained as a single dimension, as it had been originally. 
Table 3. The Results of Expletory Factor and Reliability Analysis

\section{Corporate Entrepreneurship}

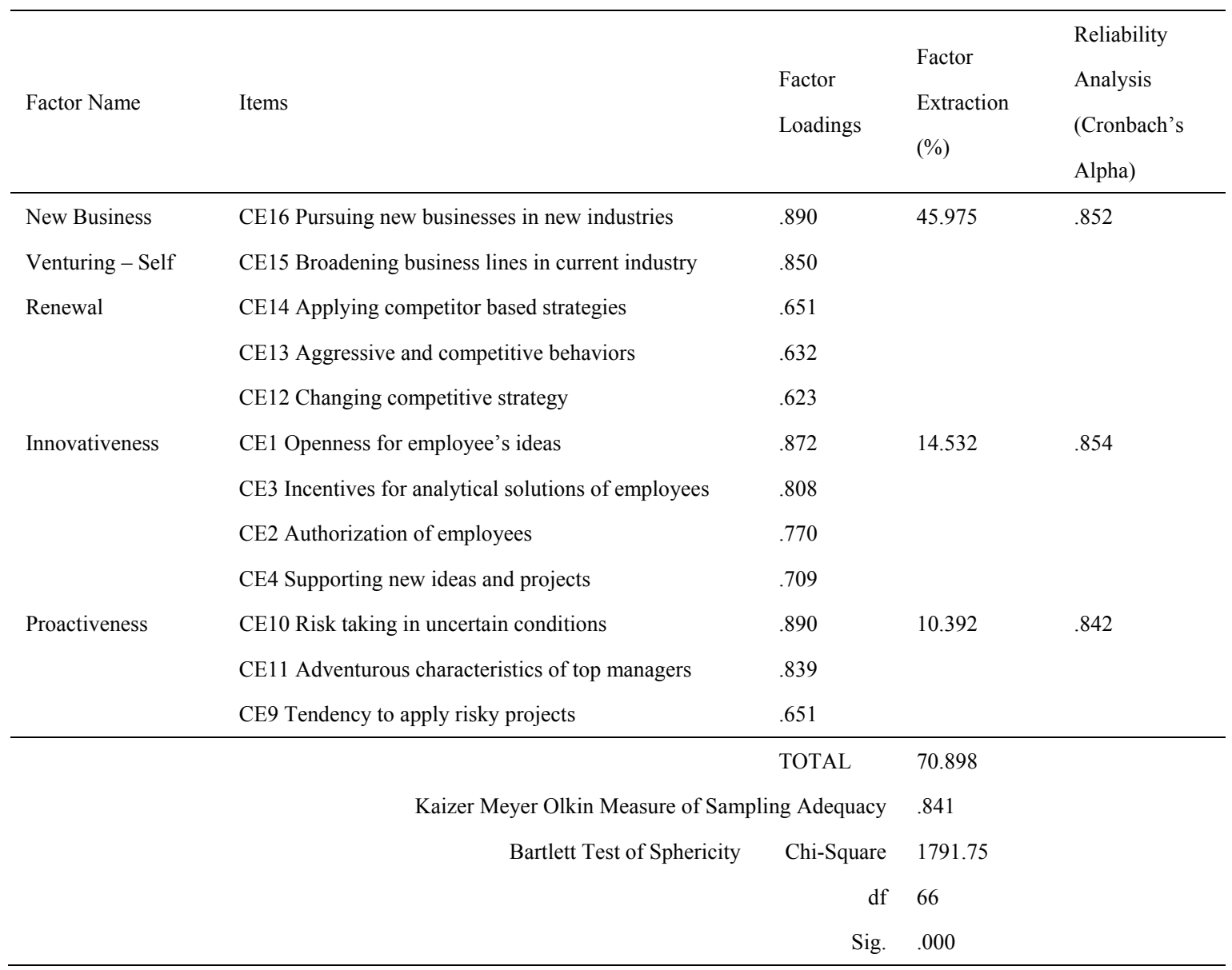


High Performance HR Practices

\begin{tabular}{|c|c|c|c|c|}
\hline \multirow[t]{4}{*}{ Factor Name } & \multirow[t]{4}{*}{ Items } & \multirow{4}{*}{$\begin{array}{l}\text { Factor } \\
\text { Loadings }\end{array}$} & \multirow{4}{*}{$\begin{array}{l}\text { Factor } \\
\text { Extraction } \\
(\%)\end{array}$} & \multirow{4}{*}{$\begin{array}{l}\text { Reliability } \\
\text { Analysis } \\
\text { (Cronbach's } \\
\text { Alpha) }\end{array}$} \\
\hline & & & & \\
\hline & & & & \\
\hline & & & & \\
\hline Clear Job Descriptions & HR18 All the duties are accurately described & .803 & 44.276 & .923 \\
\hline - Result Oriented & HR20 Objective performance appraisals & .788 & & \\
\hline \multirow[t]{4}{*}{ Appraisal } & HR17 Up-to-date job descriptions & .747 & & \\
\hline & HR19 Every employee has performance objectives & .746 & & \\
\hline & HR21 Long-term and group-based appraisals & .716 & & \\
\hline & HR16 The duties are clearly defined & .646 & & \\
\hline \multirow[t]{4}{*}{ Extensive Training } & HR7 Formal training programs to teach new hires & .846 & 11.601 & .929 \\
\hline & HR5 Extensive training programs & .825 & & \\
\hline & HR6 Training programs for employees every few years & .824 & & \\
\hline & HR8 Formal training programs are offered to employees & .689 & & \\
\hline \multirow[t]{4}{*}{ Selective Staffing } & HR3 Importance placed on staffing process & .827 & 6.611 & .948 \\
\hline & HR4 Extensive efforts in selection & .787 & & \\
\hline & HR2 Long-term employee potential is emphasized & .779 & & \\
\hline & HR1 Great effort for selecting the right person & .770 & & \\
\hline \multirow[t]{4}{*}{ Employment Security } & HR15 Employees are the last to get downsized & .790 & 5.662 & .833 \\
\hline & HR12 Employees stay with org. for as long as they wish & .784 & & \\
\hline & HR14 It is very difficult to dismiss an employee & .772 & & \\
\hline & HR13 Job security is almost guaranteed & .755 & & \\
\hline \multirow[t]{4}{*}{ Participation } & HR26 Individuals are allowed to make decisions & .835 & 4.909 & .837 \\
\hline & HR27 Employees are provided to suggest improvements & .812 & & \\
\hline & HR25 Employees are often asked to participate decisions & .769 & & \\
\hline & HR28 Open communications with employees & .688 & & \\
\hline \multirow[t]{8}{*}{ Internal Mobility } & HR10 More than one promotion positions & .824 & 4.331 & .797 \\
\hline & HR11 Supervisors know employees' career aspirations & .605 & & \\
\hline & HR9 Clear career paths in organization & .555 & & \\
\hline & & TOTAL & 77.389 & \\
\hline & \multicolumn{2}{|c|}{ Kaizer Meyer Olkin Measure of Sampling Adequacy } & .883 & \\
\hline & \multirow[t]{3}{*}{ Bartlett Test of Sphericity } & Chi-Square & 5758.039 & \\
\hline & & $\mathrm{df}$ & 300 & \\
\hline & & Sig. & .000 & \\
\hline
\end{tabular}

Organizational Support

\begin{tabular}{|c|c|c|c|c|}
\hline Factor Name & Items & $\begin{array}{l}\text { Factor } \\
\text { Loadings }\end{array}$ & $\begin{array}{l}\text { Factor } \\
\text { Extraction } \\
(\%)\end{array}$ & $\begin{array}{l}\text { Reliability } \\
\text { Analysis } \\
\text { (Cronbach's } \\
\text { Alpha) }\end{array}$ \\
\hline
\end{tabular}




\begin{tabular}{|c|c|c|c|c|}
\hline \multirow[t]{13}{*}{ Organizational Support } & OS4 Caring employees' goodness & .805 & 55.850 & .886 \\
\hline & OS1 Valuing employees' contributions & .802 & & \\
\hline & OS2 Appreciating employees' extra efforts & .754 & & \\
\hline & OS5 Noticing the extraordinary performance & .744 & & \\
\hline & OS6 Caring general satisfaction & .736 & & \\
\hline & OS7 Concerning about employees & .725 & & \\
\hline & OS8 Taking pride in employees' accomplishments & .723 & & \\
\hline & OS3 Caring complaints & .681 & & \\
\hline & & TOTAL & 55.850 & \\
\hline & Kaizer Meyer Olkin Measure of Sampling Adequacy & .868 & & \\
\hline & Bartlett Test of Sphericity & 1066.327 & & \\
\hline & $\mathrm{df}$ & 28 & & \\
\hline & Sig. & .000 & & \\
\hline
\end{tabular}

The results are confirmed by Confirmatory Factor Analysis (CFA) as in Table 4. The fit index values are mostly between admissible limits. (Anderson and Gerbing, 1984; Cole, 1987; Marsh, Balla and Mc Donald, 1988).

Table 4. The Results of Confirmatory Factor Analysis (CFA)

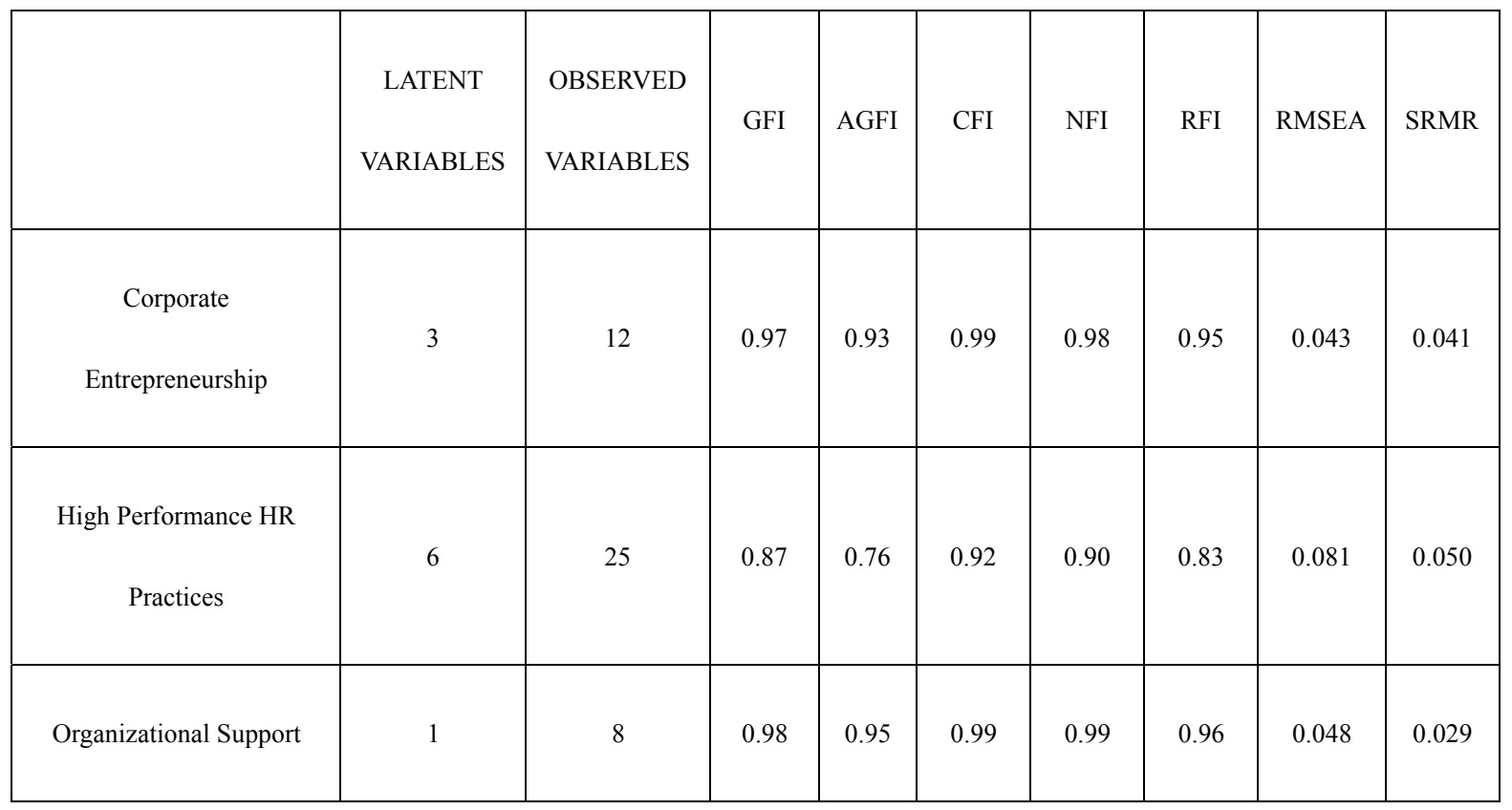

After the expletory and confirmatory factor analysis, the theoretical model is shaped as shown in Figure 2. The six dimensions of High Performance HR Practices (Clear Job Descriptions - Result Oriented Appraisal, Extensive Training, Selective Staffing, Employment Security, Participation, Internal Mobility) are predictor variables, Organizational Support is a mediator, and the three dimensions of Corporate Entrepreneurship (New Business Venturing - Self Renewal, Innovativeness, Proactiveness) are dependent variables. 


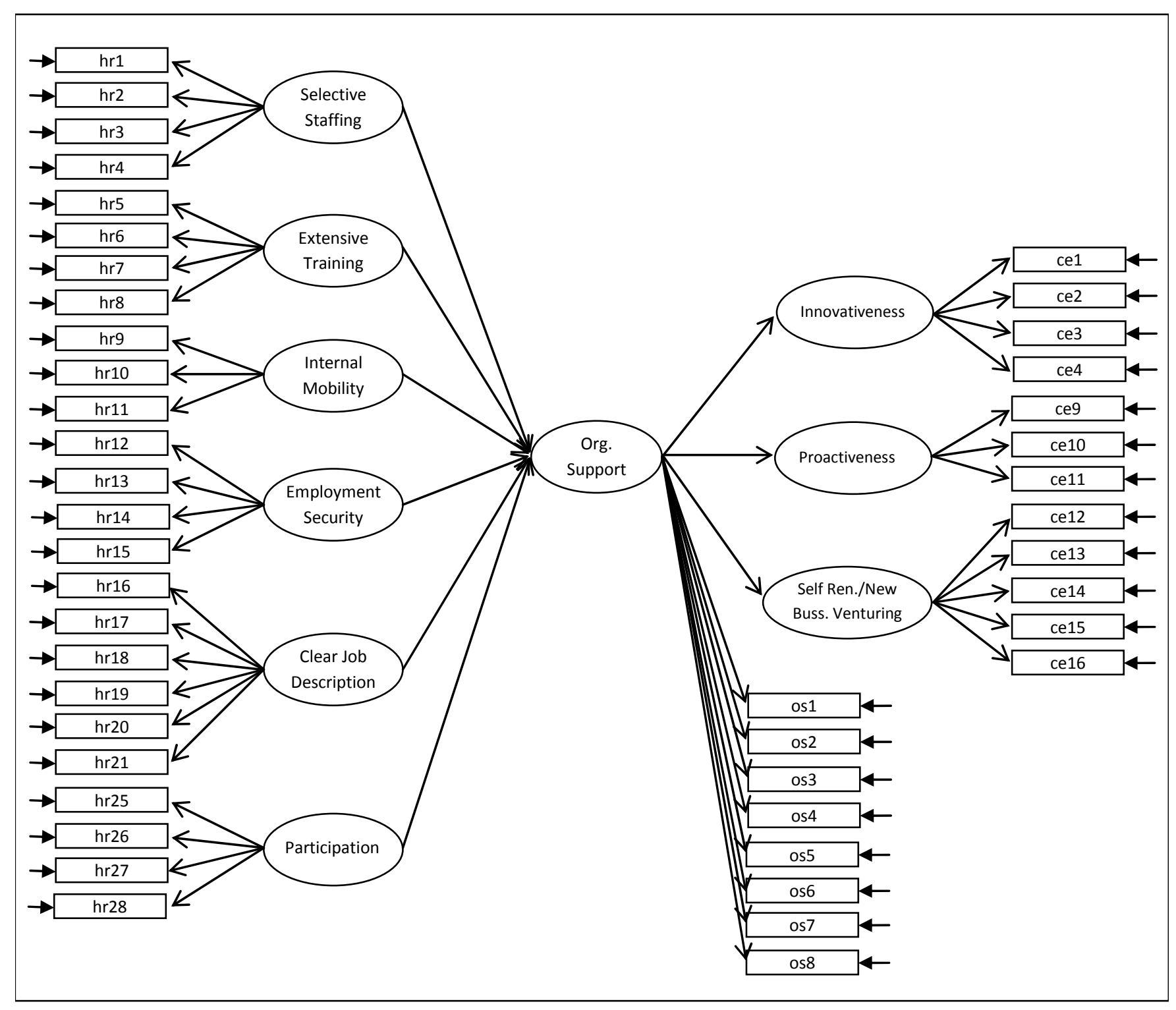

Figure 2. Theoretical Model after the Expletory and Confirmatory Factor Analysis

\section{Results and Discussion}

\subsection{Correlations}

Means, standard deviations and pearson correlation tests between the factors are shown in Table 5. As expected, all of the high performance HR activities positively and strongly affect corporate entrepreneurship. These scores are in accordance with the literature (Schuler, 1986; Kuratko et al., 1990; Morris and Jones, 1993; Hornsby et al., 1999; Twomey and Harris, 2000; Hayton, 2004; Kaya 2006; Zhang et al. 2008; Schmelter et al, 2010; Zhang and Jia 2010). Although the correlation table shows that corporate entrepreneurship, high performance human resources practices and organizational support are strongly correlated, 
the relations will be clear after the structural equation model.

It is also seen that medium and big scaled companies of the Istanbul market focus more on performing selective staffing (Mean=3,23) than on the other HR activities. Especially internal mobility and extensive training do not seem to be preferred frequently. By the way, companies are mostly aware of the importance of organizational support, which is vital for sustainable high performance. Corporate entrepreneurship scores are similar to each other.

Table 5. Correlation Tests

\begin{tabular}{|c|c|c|c|c|c|c|c|c|c|c|c|c|}
\hline & Mean & S.D. & 1 & 2 & 3 & 4 & 5 & 6 & 7 & 8 & 9 & 10 \\
\hline 1.SS & 3.23 & 1.22 & 1 & & & & & & & & & \\
\hline 2.ET & 2.65 & 1.23 & $.562^{* *}$ & 1 & & & & & & & & \\
\hline 3.IM & 2.61 & 1.02 & $.612^{* *}$ & $.598^{* *}$ & 1 & & & & & & & \\
\hline 4.ES & 2.95 & 1.00 & $.467^{* *}$ & $.262^{* *}$ & $.298^{* *}$ & 1 & & & & & & \\
\hline 5.CJD - ROA & 2.95 & 1.08 & $.665^{* *}$ & $.674^{* *}$ & $.654^{* *}$ & $.351^{* *}$ & 1 & & & & & \\
\hline 6.PAR & 2.89 & 0.95 & $.432^{* *}$ & $.276^{* *}$ & $.373^{* *}$ & $.436^{* *}$ & $.339^{* *}$ & 1 & & & & \\
\hline 7.OS & 3.27 & 0.91 & $.500^{* *}$ & $.234^{* *}$ & $.433^{* *}$ & $.457^{* *}$ & $.459^{* *}$ & $.633^{* *}$ & 1 & & & \\
\hline 8.SR - NBV & 3.28 & 0.91 & $.387^{* *}$ & $.312^{* *}$ & $.397^{* *}$ & $.313^{* *}$ & $.324^{* *}$ & $.328^{* *}$ & $.318^{* *}$ & 1 & & \\
\hline 9.PRO & 3.17 & 1.00 & $.199^{* *}$ & $.177^{* *}$ & $.278^{* *}$ & $.282^{* *}$ & $.225^{* *}$ & $.472^{* *}$ & $.407^{* *}$ & $.557^{* *}$ & 1 & \\
\hline 10.INN & 3.23 & 0.89 & $.407^{* *}$ & $.245^{* *}$ & $.379^{* *}$ & $.324^{* *}$ & $.390^{* *}$ & $.702^{* *}$ & $.592^{* *}$ & $.454^{* *}$ & $.519^{* *}$ & 1 \\
\hline
\end{tabular}

Sample Size $=258, * \mathrm{p}<0.05,{ }^{* *} \mathrm{p}<0.01$

SS: Selective Staffing, ET: Extensive Training, IM: Internal Mobility, ES: Employment Security, CJD-ROA: Clear Job Description-Result Oriented Appraisal, PAR: Participation, OS: Organizational Support, SR-NBV: Self Renewal - New Business Venturing, PRO: Proactiveness, INN: Innovativeness

Before generating the structural equation model, hierarchical regression analysis is applied to the data to see the pattern for the mediation model. This technique was used frequently for proving the mediation model until the 1990s. This technique contains three steps. In the first step, the relationship between predictor and mediator has to be significant. In the second step, the effect of the predictor on the dependent variable has to be significant. In the third and last step, when looking for the common effect of mediator and predictor on the dependent variable, the predictor has to lose its significant effect while the mediator must not. (Baron and Kenny, 1986). As seen in Table 4, all dimensions of the predictor (high performance human resources practices) are strongly correlated with the mediator (organizational support) and, as seen in the first lines (Model 1) of the analysis in Table 5, all dimensions of the predictor (high performance human resources practices) strongly affect the dependent variable (corporate entrepreneurship). 
Table 6. Analysis of the mediator role of organizational support between high performance hr practices and corporate entrepreneurship by hierarchical regression test.

\begin{tabular}{|c|c|c|c|c|c|c|c|c|c|c|c|c|}
\hline \multirow{9}{*}{$\begin{array}{l}\text { Dependent: } \\
\text { SR - NBV }\end{array}$} & Model 1 & & Model 1 & & Model 1 & & Model 1 & & Model 1 & & Model 1 & \\
\hline & (Constant) & 5.023 & (Constant) & 5.278 & (Constant) & 5.032 & (Constant) & 5.099 & (Constant) & 5.122 & (Constant) & 5.041 \\
\hline & SS & $0.231^{* *}$ & ET & $0.185^{* *}$ & IM & $0.282^{* *}$ & ES & $0.227^{* *}$ & CJD-ROA & $0.219 * *$ & PAR & $0.252^{* *}$ \\
\hline & $\mathrm{R} 2=0.146$ & & $R 2=0.094$ & & $\mathrm{R} 2=0.154$ & & $R 2=0.094$ & & $\mathrm{R} 2=0.102$ & & $R 2=0.104$ & \\
\hline & Model 2 & & Model 2 & & Model 2 & & Model 2 & & Model 2 & & Model 2 & \\
\hline & (Constant) & 4.747 & (Constant) & 4.694 & (Constant) & 4.704 & (Constant) & 4.734 & (Constant) & 4.756 & (Constant) & 4.816 \\
\hline & SS & $0.181^{* *}$ & ET & $0.149^{* *}$ & $\mathrm{IM}$ & $0.227^{* *}$ & ES & $0.154^{* *}$ & CJD-ROA & $0.152 * *$ & PAR & $0.162^{* *}$ \\
\hline & OS & $0.133^{*}$ & OS & $0.208^{* *}$ & OS & $0.144^{* *}$ & OS & $0.178^{* *}$ & OS & $0.172 * *$ & OS & $0.148^{*}$ \\
\hline & $R 2=0.164$ & & $\mathrm{R} 2=0.155$ & & $\mathrm{R} 2=0.177$ & & $R 2=0.130$ & & $\mathrm{R} 2=0.135$ & & $R 2=0.121$ & \\
\hline \multirow{9}{*}{$\begin{array}{c}\text { Dependent: } \\
\text { PRO }\end{array}$} & Model 1 & & Model 1 & & Model 1 & & Model 1 & & Model 1 & & Model 1 & \\
\hline & (Constant) & 2.647 & (Constant) & 2.793 & (Constant) & 2.466 & (Constant) & 2.345 & (Constant) & 2.558 & (Constant) & 1.737 \\
\hline & SS & $0.163^{* *}$ & ET & $0.144^{* *}$ & IM & $0.271^{* *}$ & ES & $0.281^{* *}$ & CJD-ROA & $0.209^{* *}$ & PAR & $0.497^{* *}$ \\
\hline & $\mathrm{R} 2=0.036$ & & $\mathrm{R} 2=0.028$ & & $\mathrm{R} 2=0.074$ & & $\mathrm{R} 2=0.076$ & & $\mathrm{R} 2=0.047$ & & $\mathrm{R} 2=0.220$ & \\
\hline & Model 2 & & Model 2 & & Model 2 & & Model 2 & & Model 2 & & Model 2 & \\
\hline & (Constant) & 1.714 & (Constant) & 1.596 & (Constant) & 1.586 & (Constant) & 1.552 & (Constant) & 1.657 & (Constant) & 1.435 \\
\hline & SS & -0.005 & ET & 0.07 & $\mathrm{IM}$ & $0.122 *$ & ES & 0.121 & CJD-ROA & 0.045 & PAR & $0.377^{* *}$ \\
\hline & OS & $0.451^{* *}$ & OS & $0.425^{* *}$ & OS & $0.388^{* *}$ & OS & $0.387^{* *}$ & OS & $0.423^{* *}$ & OS & $0.199 *$ \\
\hline & $R 2=0.160$ & & $\mathrm{R} 2=0.167$ & & $\mathrm{R} 2=0.172$ & & $\mathrm{R} 2=0.171$ & & $\mathrm{R} 2=0.161$ & & $\mathrm{R} 2=0.237$ & \\
\hline \multirow{9}{*}{$\begin{array}{c}\text { Dependent: } \\
\text { INN }\end{array}$} & Model 1 & & Model 1 & & Model 1 & & Model 1 & & Model 1 & & Model 1 & \\
\hline & (Constant) & 2.274 & (Constant) & 2.765 & (Constant) & 2.374 & (Constant) & 2.385 & (Constant) & 2.286 & (Constant) & 1.329 \\
\hline & SS & $0.298^{* *}$ & ET & $0.177^{* *}$ & $\mathrm{IM}$ & $0.330^{* *}$ & ES & $0.288^{* *}$ & CJD-ROA & $0.322 * *$ & PAR & $0.66^{* *}$ \\
\hline & $R 2=0.163$ & & $\mathrm{R} 2=0.056$ & & $R 2=0.140$ & & $R 2=0.102$ & & $\mathrm{R} 2=0.149$ & & $\mathrm{R} 2=0.491$ & \\
\hline & Model 2 & & Model 2 & & Model 2 & & Model 2 & & Model 2 & & Model 2 & \\
\hline & (Constant) & 1.225 & (Constant) & 1.206 & (Constant) & 1.204 & (Constant) & 1.259 & (Constant) & 1.194 & (Constant) & 0.964 \\
\hline & SS & $0.108^{*}$ & ET & $0.082 *$ & IM & $0.132 * *$ & ES & 0.061 & CJD-ROA & $0.123 * *$ & PAR & $0.514 * *$ \\
\hline & OS & $0.507^{* *}$ & OS & $0.554^{* *}$ & OS & $0.516^{* *}$ & OS & $0.549^{* *}$ & OS & $0.513^{* *}$ & OS & $0.241 * *$ \\
\hline & $\mathrm{R} 2=0.362$ & & $\mathrm{R} 2=\mathbf{0 . 3 5 7}$ & & $R 2=0.364$ & & $R 2=0.349$ & & $\mathrm{R} 2=0.363$ & & $R 2=0.526$ & \\
\hline
\end{tabular}

Regression Coefficients are given; Sample Size $=258, \quad * \mathrm{p}<0.05, * * \mathrm{p}<0.01$

SS: Selective Staffing, ET: Extensive Training, IM: Internal Mobility, ES: Employment Security, CJD-ROA: Clear Job Description-Result Oriented Appraisal, PAR: Participation, OS: Organizational Support, SR-NBV: Self Renewal - New Business Venturing, PRO: Proactiveness, INN: Innovativeness

When focusing on the second line (Model 2) in Table 5 for the third step, it becomes obvious that the mediator effects of organizational support between high performance hr practice and corporate entrepreneurship in 18 combinations of our model are:

Selective Staffing $\rightarrow$ Organizational Support $\rightarrow$ Proactiveness

Extensive Training $\rightarrow$ Organizational Support $\rightarrow$ Proactiveness 


\section{Macrothink}

Employment Security $\rightarrow$ Organizational Support $\rightarrow$ Proactiveness

Clear Job Description/Result Oriented Appraisal $\rightarrow$ Organizational Support $\rightarrow$ Proactiveness

Employment Security $\rightarrow$ Organizational Support $\rightarrow$ Innovativeness

It also becomes obvious that the key human resources practice on corporate entrepreneurship dimensions is participation. When its common effect with organizational support on self renewal/new business venturing, proactiveness and innovativeness is considered, it can be seen that participation still has powerful direct effects on all corporate entrepreneurship dimensions. These findings are also in line with the findings of Hornsby, Kuratko, and Montagno (1999); Hayton (2004) and Sun, Aryee and Law (2007).

Starting with this pattern, after several iterations applied on Lisrel 8.51, the best-fit model appeared as seen in Figure 3. The fit index values of the model were mostly between the admissible limits. While "extensive training", "employment security" and "innovativeness" were excluded from the model, "internal mobility" and "new business venturing" were included in the final "best-fit" model. The direct effects of participation decreased the model fit scores. These changes probably occurred because of the differences between unique and holistic analysis techniques. 


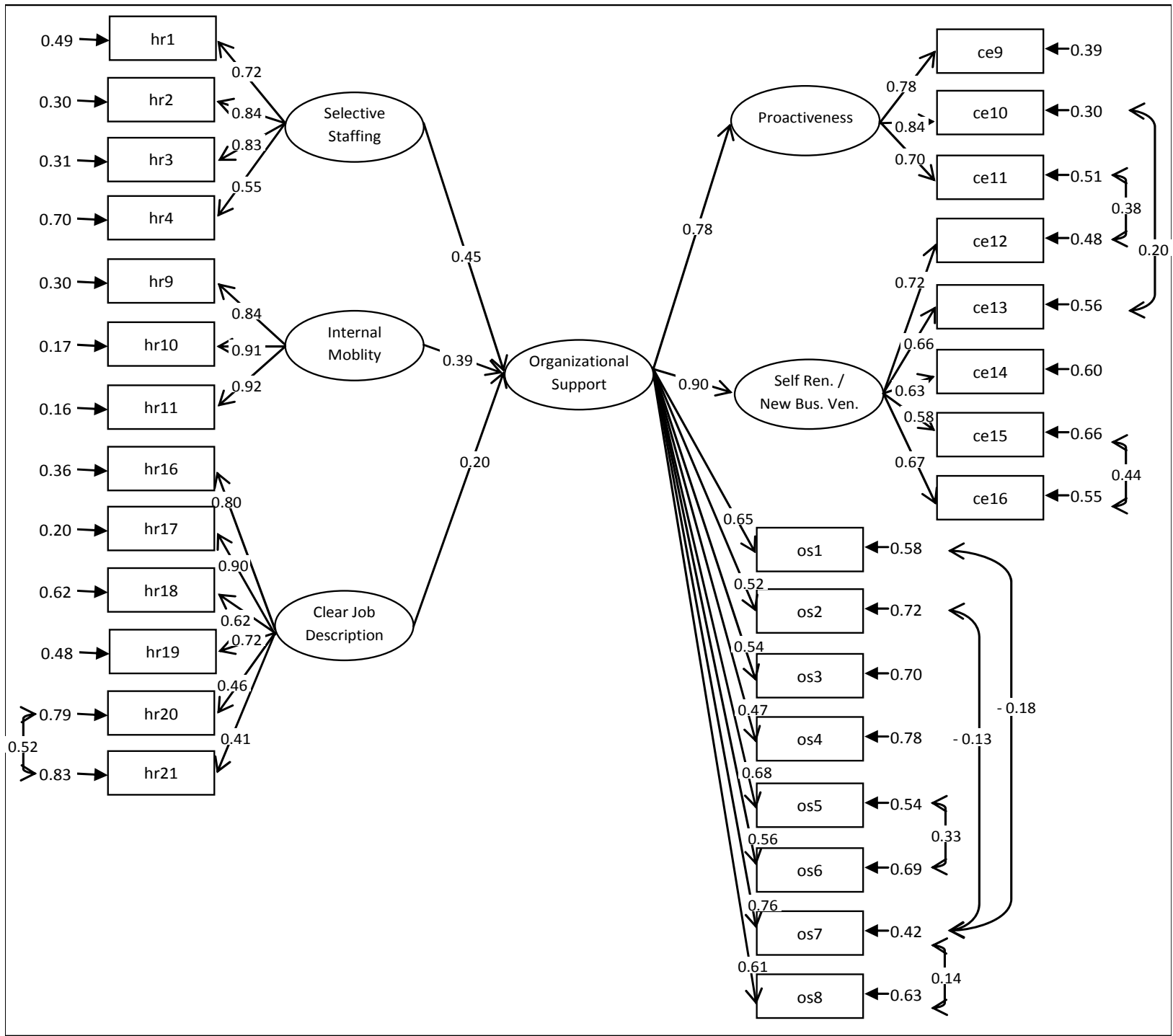

Figure 3. The Best - Fit Structural Equation Model (Standardized solution is reported. Fit indexes are: GFI:0,86; AGFI:0,76; CFI:0,90; NFI:0,86; RFI:0,80; RMSEA:0,093;

SRMR:0,085)

The model shows that proactiveness and self renewal/new business venturing of the firm are related to the three vital high performance human resources practices which are selective staffing, internal mobility and clear job description, and which can only be effective with the perception of organizational support. In other words, the effects of high performance human resources practices on proactiveness and self renewal/new business venturing lose their significance if they do not cause organizational support perception. This model also generates an overall view for the hypothesis of Antoncic and Hisrich (2004); Rutherford and Holt (2007) and Zhang and Jia (2010). 
We can easily see the importance of internal mobility, selective staffing and clear job description-result oriented appraisal in non-entrepreneurial organizations such as public utilities which mostly lack these facts. Most of them also lack organizational support like caring employees' goodness, valuing employees' contributions, and appreciating employees' extra efforts, noticing the extraordinary performance, caring general satisfaction, concerning about employees, taking pride in employees' accomplishments and caring complaints. As seen in Figure 3, although internal mobility, selective staffing and clear job description-result oriented appraisal are vital for innovativeness and proactiveness, they make no sense without perception of organizational support. This means that innovativeness and proactiveness are the result of the perception of organizational support which are generated by high performance human resources practices.

\section{Conclusion}

The results show that the positive effects of high performance HR activities on corporate entrepreneurship are very obvious. All dimensions of high performance HR activities, which are selective staffing, extensive training, internal mobility, employment security, clear job description-result oriented appraisal, and participation, directly or indirectly affect corporate entrepreneurship. The reason is that the key factor for corporate entrepreneurship is the learning process of the firms which depends on human capital. Therefore, high performance HR practices are vital for enhancing employee skills and their motivation. It's also clearly seen that participation is the most effective HR activity for developing corporate entrepreneurship. Participation of employees in decision-making does not only raise their motivation or commitment, but also increases the total creativity and the quality of new ideas.

On the other hand, if a firm lacks organizational support like caring employees' goodness, valuing employees' contributions, appreciating employees' extra efforts, noticing the extraordinary performance, caring general satisfaction, concerning about employees, taking pride in employees' accomplishments and caring complaints, most of the high performance HR activities do not affect proactiveness and self renewal/new business venturing. Our findings show that perceived organizational support does not only mediate the relations between HR activities and commitment, and organizational citizenship behavior, but also mediates the relations between HR activities and corporate entrepreneurship. Just as social exchange theory states, employees who perceive their organization as supportive feel obligated to be beneficial to the organization. In this kind of positive climate, which involves management support and work discretion, employees are more proactive and innovative, and they contribute creative ideas for corporate entrepreneurship. After this study, we have more specific arguments and a comprehensive model for defending this fact.

\section{References}

Allen David G., Lynn M. Shore, \& Rodger W. Griffeth (2003). "The Role of Perceived Organizational Support and Supportive Human Resource Practices in the Turnover Process". Journal of Management, 29(1) 99-118. http://dx.doi.org/10.1177/014920630302900107 
Anderson James C., \& David W. Gerbing. (1984). "The Effect of Sampling Error on Convergence, Improper Solutions, And Goodness of Fit Indices for Maximum Likelihood Comfirmatory Factor Analysis". Psychometrika, 49, 155-173. http://dx.doi.org/10.1007/BF02294170

Antoncic Bostjan \& Robert D. Hisrich, (2004) "Corporate entrepreneurship contingencies and organizational wealth creation". Journal of Management Development, 23(6), 518-550. http://dx.doi.org/10.1108/02621710410541114

Antoncic Bostjan \& Robert D. Hisrich. (2001). "Intrapreneurship: Construct Refinement and Cross-cultural Validation". Journal of Business Venturing, 16(5), 495-527. http://dx.doi.org/10.1016/S0883-9026(99)00054-3

Antoncic Bostjan, \& Robert D. Hisrich. (2003). "Clarifying the Intrapreneurship Concept". Journal of Small Business and Enterprise Development, 10(1), 7-24. http://dx.doi.org/10.1108/14626000310461187

Appelbaum, Eileen, Thomas Bailey, Peter Berg \& Arne L. Kalleberg. (2000). "Manufacturing advantage: Why highperformance work systems pay off". Ithaca, NY: Cornell University Press.

Baron Reuben M. \& David A. Kenny. (1986). "The Moderator-Mediator Variable Distinction in Social Psychological Research: Conceptual, Strategic, and Statistical Considerations", Journal of Personality and Social Psychology, 51(6), 1173-1182. http://dx.doi.org/10.1037/0033-295X.86.5.452

Cole David A. (1987). "Utility of Confirmatory Factor Analysis in Test Validation Research", Journal of Consulting and Clinical Psycholog, 55, 1019-1031. http://dx.doi.org/10.1037/0022-006X.55.4.584

Covin Jeffrey \& Dennis Slevin. (1991). "A conceptual model of entrepreneurship as a firm behavior". Entrepreneurship Theory and Practice, 16(1), 25-36.

Covin, Jeffrey. G., \& Dennis P. Slevin. (1986). "The development and testing of an organization-level entrepreneurship scale", in Frontiers of Entrepreneurship Research, (eds.) R Ronstadt, J. A. Hornaday, R. Peterson and K. H. Vesper M.A. Babson College, Wellesley.

Covin, Jeffry G., \& Morgan P. Miles. (1999). "Corporate Entrepreneurship and the Pursuit of Competitive Advantage". Entrepreneurship: Theory and Practice", 23(4): 47-63.

Eisenberger, Robert, Florence Stinglhamber, Christian Vandenberghe, Ivan L.Sucharski \& Linda Rhoades. (2002). "Perceived organizational support: Contribution to perceived organization support and employee retention". Journal of Applied Psychology, 87, 565-573. http://dx.doi.org/10.1037/0021-9010.86.1.42

Eisenberger, Robert, Jim Cummings, Stephen Armeli \& Patrick Lynch. (1997). "Perceived organizational Support, Discretionary Treatment, and Job Satisfaction". Journal of Applied 
Psychology, 82, 812-820. http://dx.doi.org/10.1037/0021-9010.82.5.812

Hayton James C. (2005). "Promoting corporate entrepreneurship through human resource management practices: A review of empirical research". Human Resource Management Review, 15, 21-41. http://dx.doi.org/10.1016/j.hrmr.2005.01.003

Hayton, James. C. (2004). "Strategic human capital management in SMEs: An empirical study of entrepreneurial performance". Human Resource Management Journal, 42(4), 375-391. http://dx.doi.org/10.1002/hrm.10096

Hochwarter Wayne A., Charles Kacmar, Pamela L. Perrew, \& Diane Johnson. (2003). "Perceived organizational support as a mediator of the relationship between politics perceptions and work outcomes". Journal of Vocational Behavior, 63, 438-456. http://dx.doi.org/10.1016/S0001-8791(02)00048-9

Hornsby, Jefrey. S., Donald F. Kuratko, \& Ray V. (1999). "Perception of internal factors for corporate entrepreneurship: A comparison of Canadian and U.S. managers". Entrepreneurship Theory and Practice, 24(2), 9-24.

Kaya Nihat. (2006). "The impact of human resource management practices and corporate entrepreneurship on firm performance: evidence from Turkish firms. International Journal of Human Resource Management 17, 2074-2090. http://dx.doi.org/10.1080/09585190601000204

Knight, Gary A. (1997). "Cross-cultural reliability and validity of a scale to measure firm entrepreneurial orientation". Journal of Business Venturing, 12(3), 213-225.

Kuratko, Donald F., R. Duane Ireland, Jeffrey G. Covin \& Jeffrey S. Hornsby. (2005). "A model of middle-level managers'entrepreneurial behaviour". Entrepreneurship Theory and Practice, 29(6), 699-716.

Kuratko, Donald F., Ray V. Montagno \& Jeffrey S.Hornsby. (1990). "Developing an entrepreneurial assessment instrument for an effective corporate entrepreneurial environment". Strategic Management Journal, 11, 49-58.

Lumpkin, G. T., \& Geogory. G. Dess. (1996). "Clarifying the entrepreneurial orientation construction and linking it to performance". Academy of Management Review, 21, 135-72. http://dx.doi.org/10.5465/AMR.1996.9602161568

Marsh Herbert W, John R. Balla, \& Roderick P. McDonald (1988). "Goodness of Fit Indexes in Confirmatory Factor Analysis: The Effect of Sample Size”. Psychological Bulletin, 103, 391-410. http://dx.doi.org/10.1007/BF01102761

Masterson, Suzanne S., Kyle Lewis, Barry M. Goldman, \& M. Susan Taylor. (2000). "Integrating justice and social exchange: The differing effects of fair procedures and treatment on work relationships". Academy of Management Journal, 43, 738-748. http://dx.doi.org/10.2307/1556364 
Moorman, Robert H., Gerald L. Blakely, \& Brian P. Niehoff. (1998). "Does perceived organizational support mediate the relationship between procedural justice and organizational citizenship behavior?" Academy of Management Journal, 41, 351-357. http://dx.doi.org/10.2307/256913

Morris Michael H., \& F. Jones Foard. "Human resource management practices and corporate entrepreneurship: an empirical assessment from the USA". The International Journal of Human Resource Management, 873-896. http://dx.doi.org/10.1080/09585199300000062

Özdemirci, Ata. (2011). "Corporate Entrepreneurship and Strategy Process: A Performance Based Research on Istanbul Market", The Proceedings of 7th International Strategic Management Conference. Procedia - Social and Behavioral Sciences, 24(2011), 611-626. http://dx.doi.org/10.1016/j.sbspro.2011.09.068

Podsakoff, Phillip M. \& Scott B. (1997). "The impact of organizational citizenship behavior on organizational performance: A review and suggestions for future research". Human Performance, 10(2). 133-151. http://dx.doi.org/10.1207/s15327043hup1002_5

Rhoades, Linda, Robert Eisenberger \& Stephen Armeli. (2001). "Affective commitment to the organization: The contribution of perceived organizational support". Journal of Applied Psychology, 86, 825-836. http://dx.doi.org/10.1037//0021-9010.86.5.825

Ring, J. Kirk. (2010). "The Effect of Perceived Organizational Support and Safety Climate on Voluntary Turnover in the Transportation Industry". International Journal of Business Research and Management, 1(3), 156-168

Rutherford Matthew W. \& Daniel T. Holt. (2007). "Corporate entrepreneurship: An empirical look at the innovativeness dimension and its antecedents", Journal of Organizational Change Management, 20(3), 429-446. http://dx.doi.org/10.1108/09534810710740227

Schmelter, Ralf, René Mauer, Christiane Börsch \& Malte Brettel. (2010). "Boosting corporate entrepreneurship through HRM practices: Evidence from German SMEs". Human Resource Management, 49(4), 715- 741. http://dx.doi.org/10.1002/hrm.20366

Schuler, Randall S. (1986). "Fostering and Facilitating Entrepreneurship in Organizations: Implications for Organization Structure and Human Resource Management Practices". Human Resource Management, 25(4), 607-629. http://dx.doi.org/10.1002/hrm.3930250408

Shaw, Elizabeth, Andrew O'loughlin \& Elspeth Mcfadzean. (2005), "Corporate entrepreneurship and innovation part 2: a role-and process-based approach". European Journal of Innovation Management, 8(4), 393-408. http://dx.doi.org/10.1108/14601060510627786

Sun, Li-Yun, Samuel Aryee \& Kenneth S. (2007). "High-performance human resource practices, citizenship behavior, and organizational performance: A relational perspective". Academy of Management Journal, 50(3), 558-577. 
http://dx.doi.org/10.5465/AMJ.2007.25525821

Twomey, Daniel. F., \& Drew L. Harris. (2000). "From strategy to corporate outcomes: Aligning human resource management systems with entrepreneurial intent". International Journal of Competitiveness, 10(3-4), 43-55. http://dx.doi.org/10.1108/eb047408

Wayne Sandy J., Lynn M Shore \& Robert C Linden. (1997). "Perceived organizational support and leader-member exchange: A social exchange perspective". Academy of Management Journal, 40, 82-111. http://dx.doi.org/10.2307/257021

Zahra Shaker A. (1993). "A conceptual model of entrepreneurship as firm behavior: a critique and extension". Entrepreneurship Theory and Practice, 17(4), 5-21.

Zahra Shaker A., Igor Filatotchev, \& Mike Wright. (2009). "How do threshold firms sustain corporate entrepreneurship? The role of boards and absorptive capacity". Journal of Business Venturing, 24, 248-260. http://dx.doi.org/10.1016/j.jbusvent.2008.09.001

Zahra, Shaker A. (1995). "Corporate entrepreneurship and financial performance: the management of leverage buyouts". Journal of Business Venturing, 10(3), 225-247. http://dx.doi.org/10.1016/0883-9026(94)00024-O

Zhang Zhe \& Ming Jia. (2010) "Using social exchange theory to predict the effects of high-performance human resource practices on corporate entrepreneurship: evidence from China. Human Resource Management, 49(4), 743- 765. http://dx.doi.org/10.1002/hrm.20378

Zhang, Zhe, Difang Wan, \& Ming Jia. (2008). "Do high-performance human resource practices help corporate entrepreneurship? The mediating role of organizational citizenship behavior". Journal of High Technology Management Research, 19, 128-138. http://dx.doi.org/10.1016/j.hitech.2008.10.005

\section{Copyright Disclaimer}

Copyright reserved by the author(s).

This article is an open-access article distributed under the terms and conditions of the Creative Commons Attribution license (http://creativecommons.org/licenses/by/3.0/). 